\title{
1 Free and forced gas convection in highly permeable, dry porous media
}

2 Elad Levintal ${ }^{1}$, Maria Ines Dragila ${ }^{2}$, Tamir Kamai ${ }^{1,3}$, Noam Weisbrod ${ }^{1, *}$

3 1. Environmental Hydrology and Microbiology, The Zuckerberg Institute for Water Research, The Jacob Blaustein

4 Institutes for Desert Research, Ben-Gurion University of the Negev, Israel

5 2. Department of Crop and Soil Science, Oregon State University, USA

6 3. Institute of Soil, Water and Environmental Sciences, The Agriculture Research Organization, Volcanic Center,

7 Israel

8 * Corresponding author. Tel.: +972 8 6596903; fax: +972 8 6596909. E-mail address: weisbrod@bgu.ac.il (N.

9 Weisbrod)

(C) 2016. This manuscript version is made available under the Elsevier user license http://www.elsevier.com/open-access/userlicense/1.0/ 
11 The spatial and temporal distribution of gas species within the vadose zone is determined by

12 biochemical sources and by transport mechanisms. Here, two mechanisms that can transfer gas at

13 high rates across the earth-atmosphere interface are studied. The first is thermal convection

14 venting (TCV), a free convection process that develops under conditions of sufficient

15 temperature and density gradients. The second mechanism is wind-induced convection (WIC),

16 an outcome of atmospheric surface winds that drive air movement within the porous media by a

17 forced-convection process. Both of these advective mechanisms can dominate gas transport in

18 high permeability porous media, and the objective of this study was to determine the

19 permeability values that are relevant for these mechanisms to become significant for gas

20 transport. Experiments were performed using large columns filled with four different single-

21 sized spherical particles of 1 to $4 \mathrm{~cm}$ in diameter. The experiments were conducted in a climate-

22 controlled laboratory, where surface winds and temperature gradients were imposed and

23 monitored. A tracer gas of $\mathrm{CO}_{2}$-enriched air was used to quantify the impact of TCV and WIC on

24 gas exchange between the porous media and the atmosphere. A permeability range of $10^{-7}$ to $10^{-6}$

$25 \mathrm{~m}^{2}$ was found to be sufficient for the onset of TCV when imposed temperature gradients were

26 similar to standard nighttime atmospheric conditions, leading to full or partial venting of the

27 column. Surface wind with a velocity of $1.5 \mathrm{~m} \mathrm{~s}^{-1}$ drove WIC to a depth of $0.3 \mathrm{~m}$ in most

28 experimental conditions. The impact of WIC on net gas transport was not observed at the

29 bottom-most sensor $(0.9 \mathrm{~m})$, except under conditions of very high permeability $\left(2.4 \times 10^{-6} \mathrm{~m}^{2}\right)$

30 and a large temperature difference $\left(6.5^{\circ} \mathrm{C} \mathrm{m}^{-1}\right)$, when both TCV and WIC worked

31 simultaneously. Results confirm that TCV and WIC can significantly contribute to gas transport

32 through porous media with sufficiently high permeability. 


\section{Keywords:}

\section{Gas transport}

35 Thermal convection

36 Wind-induced convection

37 High-permeability porous media

$38 \quad$ Soil aeration

39 


\section{Introduction}

41 Gas movement within the earth's subsurface and its exchange with the atmosphere is one of the

42 principal processes contributing to soil, ecosystem and atmospheric changes. Gas transport is

43 controlled by diffusive and advective mechanisms (e.g., Kuang et al., 2013 and references

44 therein), and its fate is impacted by biological, chemical, and physical processes. Vadose zone

45 source gases moving across the earth-atmosphere interface are an important source of

46 greenhouse gas emission. Significant emissions are feasible from terrestrial soils (Blagodatsky

47 and Smith, 2012; Maier and Schack-Kirchner, 2014), Landfills (Allaire et al., 2008) and other

48 environmental settings (Kang et al., 2014). Consequently, to improve our understanding of the

49 abovementioned processes and their impacts on the environment, we need to quantify the

50 mechanisms that control gas transport at the earth-atmosphere interface. This study quantifies

51 how gas exchange is controlled by conditions imposed by the physical properties of the upper

52 vadose zone and atmospheric temperature (Blagodatsky and Smith, 2012; Weisbrod et al., 2009).

53 Diffusion occurs across all permeable interfaces (Allaire et al., 2008) and historically has been

54 considered the dominant or even the only significant process for gas transport in low-

55 permeability media (Moldrup et al., 2004). With increasing permeability, transport by advection

56 may increase gas exchange rates (You and Zhan, 2013) and even dominate the process of net gas

57 flux across the earth-atmosphere interface (Massman et al., 1997; Weisbrod and Dragila, 2006).

58 Several mechanisms can drive advective gas transport at this interface: (1) thermal convection

59 venting (TCV), a type of free convection, which may develop in response to density gradients.

60 Density gradients may result from either temperature gradients in the subsurface or a temperature

61 contrast at the interface between atmospheric and porous media air (e.g., Ganot et al., 2014;

62 Kamai et al., 2009; Lahmira et al., 2014a; Nachshon et al., 2008; Nield and Kuznetsov, 2013); 
63 (2) forced wind-induced convection (WIC), which develops from surface winds that create

64 pressure differences that drive convective air circulation (e.g., Amos et al., 2009; Nachshon et

65 al., 2012; Reicosky et al., 2008; Turner and Pinshow, 2015); and (3) barometric pumping, which

66 is the inward and outward motion of subsurface air due to cycles in atmospheric pressure

67 (Neeper, 2002; Rossabi and Falta, 2002; Tillman and Smith, 2005; You and Zhan, 2013).

68 The effectiveness of the various gas transport mechanisms are determined by media properties,

69 gas properties, and atmospheric conditions. The most significant porous media properties that

70 affect gas transport are porosity, permeability, and water content (Abu-El-Sha'r and Abriola,

71 1997; Choi and Smith, 2005). Gas transport is also affected by the gas properties, namely

72 density, viscosity and solubility (Hillel, 1998). In the upper part of the vadose zone, atmospheric

73 conditions of wind, temperature and barometric pressure control the boundary condition and the

74 energy gradient driving gas transport (Poulsen and Moldrup, 2006). In this work, we focused on

75 the effect of the media's permeability and the temperature gradient on the development and

76 magnitude of TCV. The potential contribution of WIC to gas convection within the media was

77 also studied.

78 1.1. Thermal convection venting: free convection

79 Unstable gas density gradients of sufficient magnitude may drive free (natural) convection

80 within the porous media or across the porous media-atmosphere interface. A special case of

81 convective instability is driven by temperature gradients (TCV) (Lebeau and Konrad, 2009). The

82 criteria for the onset of TCV is typically defined by the Rayleigh-Darcy number $(R a)$, a

83 dimensionless number that relates convection to the ratio between gravitational (buoyancy) and

84 dissipative potentials (viscosity and thermal diffusion) for a given fluid and a given media 
85 permeability. The $R a$ number for a nonlinear temperature gradient is given as (Nield and Bejan,

86 2006; Tan et al., 2003):

$87 R a=\frac{\mathrm{g} \beta \mathrm{kH}^{2}}{v \alpha_{\mathrm{s}}} \frac{d T}{d Z}$

88 where $\mathrm{g}\left[\mathrm{m} \mathrm{s}^{-2}\right]$ is the gravitational acceleration, $\beta\left[\mathrm{K}^{-1}\right]$ is the volumetric thermal expansion

89 coefficient of the fluid, $\mathrm{k}\left[\mathrm{m}^{2}\right]$ is the permeability of the porous media, $\mathrm{H}[\mathrm{m}]$ is the characteristic

90 length of the porous media defined here as the distance from the impermeable boundary, $v\left[\mathrm{~m}^{2} \mathrm{~s}^{-}\right.$

$\left.91{ }^{1}\right]$ is the kinematic viscosity of the fluid, $\alpha_{\mathrm{s}}\left[\mathrm{m}^{2} \mathrm{~s}^{-1}\right]$ is the thermal diffusivity of the bulk porous

92 media, $T[\mathrm{~K}]$ is the temperature, and $Z[\mathrm{~m}]$ is the vertical spatial coordinate.

93 Numerical studies have explored the value of the critical $R a\left(R a_{\text {critical }}\right)$, which is defined as the

94 threshold value for the onset of TCV. A value of $R a_{\text {critical }}=27.1$ is typically used as a threshold

95 for the onset of convection in porous media, under a nonlinear temperature gradient, as is the

96 case in natural soils, and assuming homogeneous and isotropic permeability (Tan and Sam,

97 1999; Tan et al., 2003).

98 A large number of analytical methods have been suggested for estimating the permeability of

99 the media. For the case of coarse media composed of uniform spherical particles, the Kozeny-

100 Carman equation is commonly used (Bear, 1972):

$101 \quad \mathrm{k}=\frac{\mathrm{d}_{\mathrm{p}}{ }^{2}}{180} \frac{f^{3}}{(1-f)^{2}}$

102 where $\mathrm{d}_{\mathrm{p}}[\mathrm{m}]$ is the particle diameter, and $f$ is the media's air-filled porosity. Substituting Eq. 2

103 for Eq. 1 yields: 
$104 R a=\frac{\mathrm{g} \beta \mathrm{H}^{2}}{v \alpha_{\mathrm{s}}} \frac{\mathrm{d}_{\mathrm{p}}{ }^{2} f^{3}}{180(1-f)^{2}} \frac{d T}{d Z}$

105 which implies that $R a \propto \mathrm{d}_{\mathrm{p}}^{2}$ and $R a \propto d T / d Z$.

106 Only a few studies have explored TCV in porous media under natural atmospheric conditions.

107 These studies include several applications, including: waste rock dump (Lahmira et al., 2014b)

108 and natural aggregates from an agricultural field (Ganot at al., 2014). To the best of our

109 knowledge, a general relationship between TCV and either permeability or particle size (PS) has

110 not been studied. We also note that in some studies, $R a$ was calculated using an average

111 linearized $d T / d Z$ value to represent the entire system (e.g., Ganot et al., 2014). In this study, we

112 use a continuous function to represent the temperature gradient $(d T / d Z)$ for the nonlinear

113 temperature profile of the media, which is more representative of natural soil settings (Hillel,

114 1998; Holmes et al., 2008).

115 1.2. Wind-induced convection: forced convection

116 Surface wind (SW) can drive gas transport within the porous media and across its interface with

117 the atmosphere via two mechanisms: (1) Wind blowing over an irregular interface will drive

118 turbulent eddies that penetrate the subsurface zone (Brickner-Braun et al., 2014; Hillel, 1998).

119 This mechanism is effective for high-permeability media corresponding to particle diameters

120 greater than 1-2 cm (Ishihara et al., 1992). (2) High-frequency pressure changes at the interface

121 cause a pressure gradient between the interface and the porous media (Nachshon et al., 2012;

122 Poulsen and Moldrup, 2006). Even a small pressure deficit of $1 \mathrm{~Pa} \mathrm{~m}^{-1}$ at the earth-atmosphere

123 interface can drive a significant advective gas flux (Amos et al., 2009; Kimball and Lemon,

124 1972). 
125 In general, relatively few studies have explored WIC gas transport within porous media and

126 across the earth-atmosphere interface. Ishihara et al. (1992) investigated water transfer beneath

127 bare soil driven by WIC on a laboratory scale. Riley et al. (1999) studied subsurface radon

128 transport due to time-varying winds. Takle et al. (2004) examined the possible role of WIC on

129 the efflux of $\mathrm{CO}_{2}$ from the earth's subsurface. Poulsen and Moldrup (2006) and Poulsen and

130 Sharma (2011) investigated WIC effects on earth-atmosphere gas exchange for porous media,

131 focusing on landfills. Because gas fluxes in the shallow subsurface resulting from WIC can be of

132 up to one order of magnitude higher than the fluxes originating from diffusion (Takle et al.,

133 2004), further research to understand this mechanism is warranted, particularly regarding the

134 manner in which permeability mediates the effectiveness of WIC.

135 1.3. Conditions leading to the onset of free and forced convection in natural systems

136 To illustrate the potential likelihood that natural atmospheric conditions may lead to TCV and

137 WIC, temperature and wind data are presented from the Negev Desert, Israel, for a typical

138 summer (Fig. 1a) and winter day (Fig. 1b). Significant temperature differences (TDs) between

139 the atmosphere and the earth's subsurface at a depth of $1 \mathrm{~m}$ occur during the second part of the

140 night. Maximum TDs $>10^{\circ} \mathrm{C}$ and $7^{\circ} \mathrm{C}$ are evident in the summer and winter data, respectively.

141 Depending on the media permeability, these differences can potentially activate TCV. Higher

142 maximum TD values are typically expected in winter since the vadose zone is warmer than the

143 mean ambient temperature, and arid climates, like the Negev Desert, usually experience a higher

144 diurnal temperature range in the winter than in the summer (Dai et al., 1999; Ganot et al., 2014).

145 We emphasize that the TD values in Fig. 1 only indicate potential conditions for TCV. The

146 values in Fig. 1 were calculated from temperature data at only two depths as described above. In

147 order to define the location and magnitude of TCV, data of the temperature profile is needed 
148 because natural profiles are nonlinear. While TCV is likely to occur at night, SW conditions

149 suitable for WIC are evident on both summer and winter days during the afternoon. The wind

150 velocity measured at an elevation of $3.5 \mathrm{~m}$ above ground exceeded $6 \mathrm{~m} \mathrm{~s}^{-1}$ in summer and $3 \mathrm{~m} \mathrm{~s}^{-1}$

151 in winter (the blue zones in Fig. 1a and Fig. 1b). Using Eq. 2 from Nachshon et al. (2012), it can

152 be calculated that the maximum observed wind of $6 \mathrm{~m} \mathrm{~s}^{-1}$ at an elevation of $3.5 \mathrm{~m}$ is equal to 1.5

$153 \mathrm{~m} \mathrm{~s}^{-1}$ at $0.1 \mathrm{~m}$ above the surface.

154 Subsurface gas transport by convection is still an elusive research topic in soil physics and 155 subsurface transport literature. Most studies to date explored the onset of convection numerically

156 or by conducting experiments in ideal enclosures surrounded by impermeable walls (e.g.,

157 Laguerre et al., 2008; Tan et al., 2003). In addition, most studies related to TCV were performed

158 with water as the convective fluid in conditions of low to moderate permeability values, lacking

159 an investigation of gas transport in high permeability media (e.g., Nield and Kuznetsov, 2013

160 and references therein). Moreover, we could not find any published data regarding the combined

161 impact of TCV and WIC on the overall gas transport across the earth-atmosphere interface.

162 Here, we report on the relationships between the porous media permeability, $R a$ values, and the 163 development and magnitude of TCV and WIC. The reported data were obtained from

164 experiments that were conducted with large-scale columns, packed with idealized media

165 containing spherical particles. The experiments were conducted under controlled conditions, by 166 artificially forcing temperature and wind conditions.

\section{2. Materials and Methods}

168 Experiments were performed in vertical polyvinyl chloride columns, filled with spherical 169 particles. The columns were located in a climate-controlled laboratory, in which the ambient 
170 atmospheric (top) boundary condition for temperature and surface wind was controlled and

171 monitored continuously. The bottom boundary condition was controlled for temperature and

172 carbon dioxide concentration $\left[\mathrm{CO}_{2}\right]$.

\section{2.1. Climate-controlled laboratory and configuration of columns}

174 All experiments were performed under a controlled ambient air temperature of $11 \pm 0.5^{\circ} \mathrm{C}$ (see

175 Nachshon et al., 2011 and Neriah et al., 2014 for additional technical details). The columns were

$176 \quad 1.40 \mathrm{~m}$ in height and $0.3 \mathrm{~m}$ in diameter, and were subdivided into two sections: the top part was

$1771.05 \mathrm{~m}$ tall, filled with porous media, and the second part that was at the bottom was a $0.35 \mathrm{~m}$ tall

178 gas chamber (Fig. 2a), separated by a metal grid. Inside the gas chamber, an electric heater

179 (100W, Satec, Israel) maintained the desired temperature at the bottom of the column.

180 Temperature was monitored and controlled by thermocouples (type T, Omega Engineering, UK).

181 Data from all sensors were logged (CR1000, Campbell Scientific, UT, USA) at 1-min intervals.

182 Air enriched with $2000 \pm 40 \mathrm{ppm} \mathrm{CO} 2$ was chosen as the tracer gas. To maintain a constant

183 tracer concentration within the gas chamber, an enriched air tank was connected to the gas

184 chamber (Fig. 2a) via a flow control valve and inlet pipe to the gas chamber (without additional

185 outlets $)$. A continuous flow of $0.5 \pm 0.05 \mathrm{~L} \mathrm{~min}^{-1}$ was maintained and monitored using a

186 flowmeter (MR3000, Key Instruments, PA, USA). Two differential pressure sensors (1MBAR-

187 D-4V, All Sensors, CA, USA) were installed at the inlet pipe and in the gas chamber just below

188 the upper section of the column (Fig. 2a). These sensors were used to confirm that the pressure

189 that built up between the gas chamber and the above porous media did not exceed $1 \mathrm{~Pa}$ (accuracy

190 limit). Additional sensors included: (1) 20 thermocouples inside the column in groups of five at

191 four depths of $0.1,0.4,0.7$, and $1 \mathrm{~m}$ below the column's top surface; (2) a relative humidity

192 sensor (O2H-9903SD, Lutron, PA, USA) outside the column obtained the ambient relative 
193 humidity; (3) a barometric pressure sensor (MPX2100AP, Freescale Semiconductors, TX, USA);

194 and (4) two $\mathrm{CO}_{2}$ sensors (IRGAs GMD-20, Vaisala, Finland) within the column at depths of 0.3

195 and $0.9 \mathrm{~m}$ below the column's top surface, one inside the gas chamber, and one for measuring

196 the ambient concentration inside the laboratory. Further discussion on the IRGAs $\mathrm{CO}_{2}$ sensor can

197 be found at Turcu et al. (2005). The experimental setup is depicted in Fig. 2, which shows the

198 setting of the columns and sensors (Fig. 2a) and the overall laboratory (Fig. 2b).

199 2.2. Porous media

200 Polystyrene spherical particles with diameters of 1,2,3 and $4 \mathrm{~cm}$ were used as the porous

201 media; each column contained particles of a single size. These non-compressible spheres were

202 chosen because of their ideal spherical shape that allows accurate permeability calculations, and

203 because they have minimal influence on the gas, as they are impermeable and are made from

204 non-reactive materials. Each column was packed using the same packing method of continuous

205 filling while gently shaking the column. The porosity of each column was calculated as the ratio

206 of the total sphere volume to the overall column volume (Hillel, 1998). The permeability values

207 for the columns, calculated using Eq. 2, are 1.6 $\times 10^{-7}, 6.5 \times 10^{-7}, 1.3 \times 10^{-6}$, and $2.4 \times 10^{-6} \mathrm{~m}^{2}$

208 for the PS diameters of 1, 2, 3, and $4 \mathrm{~cm}$, respectively.

209 2.3. Tracer gas

210 The tracer gas for the experiment was air enriched with $2000 \mathrm{ppm} \mathrm{CO}_{2}$ (Maxima, Israel). This

211 concentration was chosen as it has no significant impact on the air density (Kowalski and

212 Sánchez-Cañete, 2010). Additionally, because the experiments were conducted in dry media, the

213 high solubility of $\mathrm{CO}_{2}$ in water had no impact on its mobility in the gas phase.

\section{2.4. Wind tunnel}


215 A wind tunnel with a constant wind velocity was used for simulating natural SW conditions

216 corresponding to those measured by a meteorological station in the Negev Desert (Fig. 1, blue

217 lines). The tunnel size and cross-sectional area were customized to our columns following

218 Ishihara et al. (1992). The tunnel was constructed from a standard air ventilation fan connected

219 to a $0.5 \times 0.4 \times 0.4 \mathrm{~m}$ wood tunnel. The tunnel outlet included a grid of 81 metal pipes, each

$220 \quad 0.038 \mathrm{~m}$ in diameter and $0.18 \mathrm{~m}$ in length. The wind was measured at different heights above the

221 column, at a distance of $0.2 \mathrm{~m}$ from the outlet, using a handheld device (C400, Lufft, Germany).

222 An average wind velocity of $1.5 \mathrm{~m} \mathrm{~s}^{-1}$ was sustained $0.1 \mathrm{~m}$ above the column in all experiments

223 were wind was applied.

\section{2.5. Experimental procedure}

225 Experiments were designed to test gas transport for four media properties (i.e., sphere 226 diameters) under six different conditions that varied in either TD or SW: (1) isothermal 227 conditions (TD0), with no SW (control condition); (2) TD1 and no SW; (3) TD2 and no SW; (4)

228 TD0 and SW; (5) TD1 and SW; and (6) TD2 and SW. Each experimental condition was

229 performed on all four PSs, with three repetitions, such that overall, 72 experiments were

230 conducted. The TD conditions imposed were: $\mathrm{TD} 0=0 \pm 0.5^{\circ}, \mathrm{TD} 1=3.5 \pm 0.5^{\circ}$, and TD2 $=6.5$

$231 \pm 0.5^{\circ} \mathrm{C}$. The TD values represent the difference between the temperature measured at the

232 bottom of the porous media and that of the ambient air measured above the column. The

233 temperature differences were imposed by heating the bottom of the column using an electric

234 heater inside the gas chamber that was automated to maintain the desired temperature, except for

235 TD0. A warmer temperature at the bottom was imposed in order to mimic nighttime soil

236 conditions with cold atmospheric air above warm soil air (Holmes et al., 2008). Experiments 
237 with imposed SW applied a constant wind of $1.5 \mathrm{~m} \mathrm{~s}^{-1} 0.1 \mathrm{~m}$ above the top of the column

238 surface.

239 2.6. Tracer gas analysis: relative concentration calculation

240 The extent of the convective mechanism in the mixing of air between the atmosphere and the

241 media was quantified by comparing the $\left[\mathrm{CO}_{2}\right]$ at a depth of $0.9 \mathrm{~m}$ in the media to the ambient

242 concentration. To separate the contribution of convection from background fluxes resulting from

243 diffusion and the small measured advective component resulting from the inlet flow rate $(0.5 \mathrm{~L}$

$244 \min ^{-1}$ ), we normalized each value to the value obtained during the isothermal experiment runs.

245 The extent of venting is thus represented by a relative concentration parameter, calculated as:

246 Relative Concentration $=\frac{\mathrm{C}_{0.9}-\mathrm{C}_{\mathrm{atm}}}{\mathrm{C}_{\mathrm{TD} 0}-\mathrm{C}_{\mathrm{atm}}}$

247 where $\mathrm{C}_{0.9}[\mathrm{ppm}]$ is the $\left[\mathrm{CO}_{2}\right]$ under convective venting conditions, $\mathrm{C}_{\mathrm{TD} 0}$ [ppm] is the average

$248\left[\mathrm{CO}_{2}\right]$ under isothermal (TD0), steady-state conditions, both at a depth of $0.9 \mathrm{~m}$ for the same PS,

249 and $\mathrm{C}_{\mathrm{atm}}[\mathrm{ppm}]=365 \mathrm{ppm}$ is the $\left[\mathrm{CO}_{2}\right]$ of the laboratory room. Steady-state conditions were

250 defined as less than a $1 \%$ change in $\left[\mathrm{CO}_{2}\right]$ in all sensors over at least 10 minutes. It is expected

251 that the relative concentration will equal unity when there is no convective venting, and zero

252 under full convective venting.

\section{$253 \quad 3 . \quad$ Results and Discussion}

254 Porosity values for all columns were between 0.44 and 0.45 (Table 1, column A), close to the 255 ideal 0.40 value for cubic tetrahedral packing (Hillel, 1998).

256 3.1. Air movement under isothermal conditions 
257 Under isothermal conditions ( $\mathrm{TD}=0 \pm 0.5^{\circ} \mathrm{C}$; Table 1, column $\mathrm{C}$ ), we verified that convective 258 motion did not occur within any of the columns (within measurement error). $\left[\mathrm{CO}_{2}\right]$ values at the

259 0.9-m depth were close to the influx $\left[\mathrm{CO}_{2}\right]$ of 2000 ppm (Table 1, column D), indicating

260 minimal mixing. When wind was imposed, WIC venting reached approximately a $0.3-\mathrm{m}$ depth in

261 all columns except for PS $=1 \mathrm{~cm}$, dropping the tracer concentration by $15 \pm 5 \%$. The observed

262 decrease in the $\left[\mathrm{CO}_{2}\right]$ at a depth of 0.3 m agrees with previous studies. Takle et al. (2004)

263 observed wind-driven high pressure fluctuations at a depth of $0.15 \mathrm{~m}$. WIC at a depth of $0.3 \mathrm{~m}$ in

264 tillage soils was reported by Reicosky et al. (2008), and in large aperture fractures, up to a depth

265 of $0.5 \mathrm{~m}$ (Nachshon et al., 2012). Since wind tunnel may generate less turbulence than natural

266 wind, WIC may be more pronounced under field conditions (Waddington et al., 1996) than

267 observed here.

\section{3.2. Air movement under temperature differences}

269 When TD conditions were imposed between the bottom of each column and the laboratory air,

270 TCV occurred in all columns except for PS = $1 \mathrm{~cm}$ (Table 1, column E). The magnitude of

271 convective gas mixing increased with increasing PS and TD values, indicated by a decrease in

$272\left[\mathrm{CO}_{2}\right]$ at $0.9 \mathrm{~m}$. For example, for TD2, $\left[\mathrm{CO}_{2}\right]$ at $0.9 \mathrm{~m}$ decreased by $10 \%$ and $71 \%$ for PS $=2$ and

$273=4 \mathrm{~cm}$, respectively. These results agree with the general behavior predicted by Eq. 3, which

274 shows that TCV, which is amplified with the increase of the $R a$ number (Nield and Bejan, 2006),

275 should be proportional to the temperature gradients and the permeability (square of the PS). TD

276 values used in the experiment were chosen to be in the range of field data (Fig. 1, red zone) and

277 reported in previous studies (e.g., Ganot et al., 2012; Ninari and Berliner, 2002; Smith et al.,

278 2012). The imposed TD conditions resulted in nonlinear temperature gradients, with the gradient

279 exponentially decaying away from the heat source (Fig. 3). The slight differences between the 
280 temperature profiles for the same TD are the results of small variations in laboratory temperature 281 and thermocouple locations between the different experiments.

282 A continuous temperature profile was obtained by fitting to the data an exponential temperature 283 distribution function that decays from the heat source (the electric heater in the gas chamber at 284 the bottom of the column),

$285 T=\mathrm{X}_{1}+\mathrm{X}_{2} \exp ^{\left[\mathrm{X}_{3}(Z+1.05)\right]}$

286 where $T\left[{ }^{\circ} \mathrm{C}\right]$ is the calculated temperature, $Z[\mathrm{~m}]$ is the depth from the surface (negative

287 downward), and $\mathrm{X}_{\mathrm{i}}$ (with $\mathrm{i}=1,2$, or 3 ) are fitting parameters. For each experimental condition,

288 Eq. 5 was fitted using a least squares optimization to the data from the three repetitions of each

289 experiment, using temperature data measured at the six different depths (Fig. 3). Eight equations

290 corresponding to four PS and two TD values were obtained from this fitting exercise, with $\mathrm{R}^{2}>$

2910.96.

292 Because the $R a$ number provides a theoretical indicator for the onset of free convection and the

293 occurrence and magnitude of TCV, continuous $R a$ values were evaluated from the temperature

294 data. The derivative of Eq. 5 (Eq. 6) was used to obtain a continuous $d T / d Z$ function for

295 calculating $R a$ values for each column (Fig. 4).

$296 \frac{d T}{d Z}=\mathrm{X}_{3} \mathrm{X}_{2} \exp ^{\left[\mathrm{X}_{3}(Z+1.05)\right]}$

297 Regions within the media are locally active with TCV when $R a>R a_{\text {critical, }}$ and, in contrast, are 298 not active when $R a<R a_{\text {critical }}$ corresponding to sections of stable density gradients. For our 299 analysis, we used $R a_{\text {critical }}=27.1$, typical for a nonlinear temperature distribution (Tan and Sam, 300 1999; Tan et al., 2003). The section within the column that is active in TCV is quantified by the 
301 convection cell length, calculated to be the distance from the bottom of the porous media (where

302 it is warmest, and the $R a$ greatest) up to where the $R a$ line crosses $R a_{\text {critical }}(\mathbf{F i g . ~ 4}$, Table $\mathbf{1}$,

303 column G). For each TD condition, the convection cell lengths increased with increasing PS

304 value; and for each PS value, all cell lengths increased with the increasing TD. An average $R a$

305 for each convection cell ( $R a_{\text {avg; }}$, Table $\mathbf{1}$, column $\left.\mathrm{H}\right)$ was calculated using nonlinear averaging of

306 Eq. 1 with the temperature values of the top and bottom boundaries of the convection cell as the

307 integration boundaries. The convection cell length and $R a_{\text {avg }}$ characterize the TCV state, with the

308 first describing the spatial extent of the convective mixing region and the second parameter

309 describing the magnitude of gas mixing. Two mixing regions can have similar spatial

310 distributions, but their magnitudes can be different, thus causing different gas concentration

311 changes inside a similar cell length. The magnitude of gas mixing will always be greatest at the

312 location of the greatest temperature gradient; in this experiment, the location is the end of the cell

313 closest to the heat source, but under natural conditions, the depth of the maximum temperature

314 gradient varies diurnally.

315 The relationship shown in Fig. 5a provides the link between experimental results and the

316 theoretical prediction of convection with $R a$. If $R a$ predicts the convective venting intensity and

317 location, then increases in cell length will correlate to decreasing gas concentration at the $0.9-\mathrm{m}-$

318 depth sensor. Indeed, our results show a linear relationship $\left(\mathrm{R}^{2}>0.91\right)$ between the convection

319 cell length and the relative $\left[\mathrm{CO}_{2}\right]$ (Fig. 5a) measured by the 0.9-m sensor. Results in Fig. 5a

320 demonstrate that internal cells driven by temperature gradients within the porous media can

321 control gas exchange with the atmosphere, as evidenced by the decrease in tracer gas

322 concentrations. 
323 While the sensor at $0.9 \mathrm{~m}$ is an indication of net loss, the mixing caused by convection within

324 the porous media is evidenced by the decrease of the tracer concentrations in the profile. A

325 progressive decrease in tracer concentrations along the profile between the 0.3- and 0.9-m

326 sensors was more pronounced with increase in PS and TD (Fig. 5b). For PS = 4 and TD2, the

327 convection cell reached up to the 0.3-m sensor; consequently, the gas was fully mixed and the

328 concentration profile was flat. In all other cases, the cell did not reach the $0.3-\mathrm{m}$ sensor, but its

329 effect was evident in the reduced concentration differences between these two sensors. Ganot et

330 al. (2014) also observed flat concentration gradients when exploring convection in a column

331 packed with large aggregates collected from an agricultural field (estimated permeability of 2.4

$332 \times 10^{-6} \mathrm{~m}^{2}$, similar to the permeability for the PS $=4 \mathrm{~cm}$ ) when a TD promoting TCV was

333 applied. Under natural conditions, TCV acting within the root zone can accelerate the

334 equilibration of soil gases with the atmosphere, subsequently increasing soil aeration.

335 In the scenarios explored in this study, the calculation of $R a$ values indicates that all the

336 convection cells ended below the upper boundary, thus causing "closed inner cells" in the media.

337 It is evident from the data that even internal cells increase the net gas flux by reducing the

338 diffusion transport distance, thus increasing the concentration gradient driving diffusion (Rose

339 and Guo, 1995). In the case of cells that reach the earth-atmosphere interface, atmospheric $\mathrm{CO}_{2}$

340 values are expected throughout the media whenever the time constant of gas production is lower

341 than the convective time constant. The extreme case of such conditions is an open fracture

342 system (Kamai et al., 2009; Nachshon et al., 2008; Weisbrod and Dragila, 2006; Weisbrod et al., 343 2009).

344 While the effect of wind did not reach deep into the profile $(\sim 0.3 \mathrm{~m})$, WIC mixing of the upper 345 profile resulted in a reduction in the gas concentration at the $0.3-\mathrm{m}$ sensor for all columns in 
346 which PS $>1 \mathrm{~cm}$. In the case of TD2 and PS $=3$ and $4 \mathrm{~cm}$, WIC mixing and the TCV convection

347 cell linked to flatten the entire gas profile. These findings indicate the potential for a linkage

348 between free and forced convection mechanisms in natural systems. Each mechanism has a

349 region of influence; when these overlap, the two mechanisms could synergize into a more

350 complete and effective venting process. In high-permeability media under field conditions, the

351 diurnal variability of the media's thermal gradient could lead to regular, short-lived, but

352 effective, media gas-flushing events.

353 3.3. Impact of natural soil temperature profiles on soil gas convection: theoretical

354 calculations

355 The same analysis to determine location and extent of internal TCV cells which was used for

356 the laboratory columns is applied here to soil profile temperatures to investigate the extent of the

357 impact of TCV on subsurface gas motion and gas efflux. The soil temperature profile resulting

358 from downward conduction of a surface sinusoidal temperature wave is given by Hillel (1998):

$359 T(Z, \mathrm{t})=T_{\mathrm{avg}}+\mathrm{A}_{0}\left[\sin \left(\omega \mathrm{t}+\frac{Z}{\mathrm{~d}}\right)\right] \exp ^{\frac{Z}{\mathrm{~d}}}$

360 where $T_{\text {avg }}[\mathrm{K}]$ is the average temperature of the soil surface, $\mathrm{A}_{0}[\mathrm{~K}]$ is the daily amplitude of the

361 surface temperature, $\omega\left[\mathrm{s}^{-1}\right]$ is the radial diurnal frequency, $\mathrm{t}[\mathrm{s}]$ is the time, $Z[\mathrm{~m}]$ is the depth

362 (negative downward), and $\mathrm{d}[\mathrm{m}]$ is the damping depth defined as

$363 \mathrm{~d}=\left(\frac{2 \alpha_{s}}{\omega}\right)^{0.5}$

364 where $\alpha_{\mathrm{s}}\left[\mathrm{m}^{2} \mathrm{~s}^{-1}\right]$ is the thermal diffusivity of the bulk soil. 
365 A continuous thermal gradient function was obtained by differentiating Eq. 7, and $R a$ values

366 were calculated using Eq. 1, were $\mathrm{H}$ was equaled to the damping depth to represent the distance

367 over which the temperature difference is significantly expressed. Incorporating a nonlinear

368 temperature gradient elucidated an additional phenomenal not previously reported. As an

369 example, two times of day are here analyzed, 04:00 AM and 08:00 AM. The temperature profile

370 at 04:00 AM (Fig. 6a1) shows an unstable upper section of cold air above warmer air, starting at

$37111.3^{\circ} \mathrm{C}$ at the soil-atmosphere interface and increasing with depth, reaching $R a_{\text {critical }}$ (i.e., $R a=$

372 27.1) at a depth of $\sim 0.33 \mathrm{~m}$ (Fig. 6a3). During this time period, a convection cell stretching from

373 the surface to a depth of $0.33 \mathrm{~m}$ is predicted. At 08:00 AM (Fig. 6b1), the upper 0.09 $\mathrm{m}$ has a

374 stable gradient, but between a depth of $0.09 \mathrm{~m}$ and a depth of $0.46 \mathrm{~m}$, the thermal gradient is

375 unstable (Fig. 6b2). $R a$ values predict an internal convection cell in the middle section where

376 cold resides above warm air, with the cell stretching from depth of 0.10 to $0.41 \mathrm{~m}$ (Fig. $\mathbf{6 b 3})$. In

377 both cases, the convection cell was $\sim 0.3 \mathrm{~m}$ long, but located very differently within the profile. A

378 cell that reaches the soil-atmosphere interface (e.g., 04:00 AM) will enable direct advective gas

379 transport between the soil and the atmosphere. Internal TCV cells will homogenize internal gas

380 gradients and will shorten the distance over which diffusion controls transport, increasing net

381 efflux. At 04:00 AM, the cell is already connected to the surface, and venting is presumably

382 already faster than gas generation processes within the soil profile.

383 Our study emphasizes the need to quantify $R a$ as a continuous property for the entire porous

384 media profile, rather than using temperature values from a few discrete points, as sparse discrete

385 values can lead to erroneous TCV interpretations. For example, using Figs. $6 \mathbf{3} 3$ and $\mathbf{6 b 3}$, and

386 calculating the $R a$ number based on a linear $\Delta T / \Delta Z$ between only two points $(\mathrm{Z}=0$ and $0.5 \mathrm{~m})$

387 gives $\Delta T / \Delta Z$ equal to 17.2 and 0 , and $R a$ equal to 308.3 and 0 , at 04:00 and 08:00 AM, 
respectively. These results will lead to the wrong conclusion that a full convection cell of a length of 0.5 m is initiated at 04:00 AM, and no cell at 08:00 AM as $R a<R a_{\text {critical. }}$

390 The experiments and theoretical analysis presented here investigated dry porous media

391 conditions and homogeneous permeability. Under natural conditions, heterogeneous

392 permeability, water content and vapor dynamics (evaporation and condensation) are expected to

393 affect the convection process by changing the temperature profile and the air-filled porosity

394 (Eqs. 2, 7 and 8), impacting the criteria leading to TCV onset. Our results show that for low

395 permeability $\left(<10^{-7} \mathrm{~m}^{2}\right) \mathrm{TCV}$ is unlikely to occur under natural daily changes of temperature. In

396 other words, in sandy or finer soils, unless there are large aperture cracks $(\sim 1 \mathrm{~cm}$; Nachshon et

397 al., 2008), TCV is unlikely to be developed. Also large pores (above capillary size) between

398 aggregates tend to drain fast by gravity and therefore will be empty most of the time, facilitating

399 convection.

\section{$400 \quad 4 . \quad$ Summary and conclusion}

401 The main objective of this research was to establish relationships between permeability and 402 convective venting under imposed (1) thermal gradients within the porous media; (2) surface 403 wind; and (3) these conditions combined. Column experiments were conducted under controlled 404 laboratory conditions, using columns filled with single-sized spherical particles.

405 For the temperature gradients imposed, results clearly show a permeability cutoff $\left(\sim 1.6 \times 10^{-7}\right.$

$406 \mathrm{~m}^{2}$ ) below which thermal convection did not develop. Above this permeability cutoff, convective

407 venting increased with permeability and temperature gradient. TCV caused significant gas

408 mixing between the porous media and the ambient atmospheric air above. Relative $\left[\mathrm{CO}_{2}\right]$ at a

409 depth of $0.9 \mathrm{~m}$ decreased down to $29 \%$ during TCV for the largest particle size $(4 \mathrm{~cm})$ with an 
410 imposed temperature difference of $6.5^{\circ} \mathrm{C}$, compared to the isothermal case. The permeability

411 cutoff value identified by this study suggests that for sand size particles and below, TCV is an

412 insignificant contributor to gas transport.

413 The addition of a $1.5 \mathrm{~m} \mathrm{~s}^{-1}$ surface wind enhanced the circulation of atmospheric air to a depth 414 of $0.3 \mathrm{~m}$ for particles greater than $1 \mathrm{~cm}$. For the largest particle size $(4 \mathrm{~cm})$ and under the highest 415 temperature difference $\left(\mathrm{TD} 2=6.5^{\circ} \mathrm{C}\right)$, the upper convective cell driven by WIC was linked with 416 the lower TCV cell venting the entire column, lowering the concentration at the bottom of the 417 column to $9 \%$, the lowest value compared to all the other conditions.

418 By measuring tracer gas concentration and calculating $R a$ values from temperature data, it was 419 possible to link between experimental data and the theoretical prediction of convection.

420 Observed changes in tracer gas concentration showed an excellent correlation to the convection 421 cell length derived from the theoretical $R a$ values. This correlation supports the potential of the 422 future prediction of TCV from measured soil temperature profiles and physical properties, 423 mainly permeability and thermal parameters. This approach was tested using field soil 424 temperature profiles. The nonlinear temperature gradient required that $d T / d Z$ and the resulting $R a$ 425 values should be analyzed as a continuous curve and not as discrete values along the profile. This 426 analysis elucidated the existence of internal convection cells that develop and do not necessarily 427 reach the earth-atmosphere interface. Such cells would cause internal mixing of soil gases within 428 the convection cell with an effect on the net gas transport by shortening the distance over which 429 diffusion is acting. Our analysis also demonstrates that only a small temperature data set is 430 necessary to provide an accurate prediction of convective gas transport. 
431 Different transport mechanisms affect gas movement across the earth-atmosphere interface.

432 Here, we evaluated the impact of free convection driven by temperature gradients, internal to the

433 porous media, on the enhancement of gas transport across the media-atmosphere interface. In

434 addition, we also tested the influence of wind-induced convection and the potential synergy

435 between the two mechanisms. The results of this study indicate that convection, even if only

436 existing internally within the media, can enhance gas transport significantly above the rates

437 driven by diffusion. 


\section{Acknowledgments}

440 This work was funded by the Israeli Science Foundation (ISF), contract 678/11, The Bi-

441 National Science Foundation (BSF) contract number (2014220), and the Israeli Ministry of

442 Agriculture, contract 857- 0686-13. We also acknowledge the Sam Zuckerberg scholarship

443 provided to EL and the two anonymous reviews helped to improve this manuscript.

444

445 


\section{References}

447 Abu-El-Sha'r, W., Abriola, L.M., 1997. Experimental assessment of gas transport mechanisms in 448 natural porous media: Parameter evaluation. Water Resour. Res. 33, 505-516. doi:10.1029/96WR03536

\section{0}

452

Al Nakshabandi, G., Kohnke, H., 1965. Thermal conductivity and diffusivity of soils as related to moisture tension and other physical properties. Agric. Meteorol. 2, 271-279. doi:10.1016/0002-1571(65)90013-0

Allaire, S.E., Lafond, J.A., Cabral, A.R., Lange, S.F., 2008. Measurement of gas diffusion through soils: comparison of laboratory methods. J. Environ. Monit. 10, 1326-1336. doi:10.1039/b809461f

Amos, R.T., Blowes, D.W., Smith, L., Sego, D.C., 2009. Measurement of Wind-Induced Pressure Gradients in a Waste Rock Pile. Vadose Zo. J. 8, 953-962. doi:10.2136/vzj2009.0002

Bear, J., 1972. Dynamics of fluids in porous media. American Elsevier Pub. Co., NY.

Ben Neriah, A., Assouline, S., Shavit, U., Weisbrod, N., 2014. Impact of ambient conditions on evaporation from porous media. Water Resour. Res. 50, 6696-6712. doi:10.1002/2014WR015523

Blagodatsky, S., Smith, P., 2012. Soil physics meets soil biology: Towards better mechanistic prediction of greenhouse gas emissions from soil. Soil Biol. Biochem. 47, 78-92. doi:10.1016/j.soilbio.2011.12.015

Brickner-Braun, I., Zucker-Milwerger, D., Braun, A., Turner, J.S., Pinshow, B., Berliner, P., 2014. Ventilation of multi-entranced rodent burrows by boundary layer eddies. J. Exp. Biol. 
Choi, J.-W., Smith, J. a., 2005. Geoenvironmental Factors Affecting Organic Vapor Advection and Diffusion Fluxes from the Unsaturated Zone to the Atmosphere under Natural Conditions. Environ. Eng. Sci. 22, 95-108. doi:10.1089/ees.2005.22.95

\section{2}

473

474

475

476

477

478

479

480

481

482

483

484

485

486

487

488

489

Christophersen, M., Kjeldsen, P., Holst, H., Chanton, J., 2001. Lateral gas transport in soil adjacent to an old landfill: Factors governing emissions and methane oxidation. Waste Manag. Res. 19, 595-612.

Dai, A., Trenberth, K.E., Karl, T.R., 1999. Effects of Clouds, Soil Moisture, Precipitation, and Water Vapor on Diurnal Temperature Range. J. Clim. 12, 2451-2473. doi:10.1175/15200442(1999)012<2451:EOCSMP>2.0.CO;2

Ganot, Y., Dragila, M.I., Weisbrod, N., 2014. Impact of thermal convection on CO2 flux across the earth-atmosphere boundary in high-permeability soils. Agric. For. Meteorol. 184, 1224. doi:10.1016/j.agrformet.2013.09.001

Ganot, Y., Dragila, M.I., Weisbrod, N., 2012. Impact of thermal convection on air circulation in a mammalian burrow under arid conditions. J. Arid Environ. 84, 51-62. doi:10.1016/j.jaridenv.2012.04.003

Hillel, D., 1998. Environmental Soil Physics. Academic Press, San Diego, CA.

Holmes, T.R.H., Owe, M., De Jeu, R.A.M., Kooi, H., 2008. Estimating the soil temperature profile from a single depth observation: A simple empirical heatflow solution. Water Resour. Res. 44, n/a-n/a. doi:10.1029/2007WR005994

Incropera, F.P., DeWitt, D.P., Bergman, T.L., Adrienne, S.L., 2007. Fundamentals of Heat and Mass Transfer, sixth. ed. John Wiley \& Sons, Hoboken, NJ. 
Ishihara, Y., Shimojima, E., Harada, H., 1992. Water vapor transfer beneath bare soil where evaporation is influenced by a turbulent surface wind. J. Hydrol. 131, 63-104. doi:10.1016/0022-1694(92)90213-F

Kamai, T., Weisbrod, N., Dragila, M.I., 2009. Impact of ambient temperature on evaporation from surface-exposed fractures. Water Resour. Res. 45, 1-11. doi:10.1029/2008WR007354

Kang, M., Kanno, C.M., Reid, M.C., Zhang, X., Mauzerall, D.L., Celia, M.A., Chen, Y., Onstott, T.C., 2014. Direct measurements of methane emissions from abandoned oil and gas wells in Pennsylvania. Proc. Natl. Acad. Sci. 111, 18173-18177.

Kimball, B.A., Lemon, E.R., 1972. Theory of soil air movement due to pressure fluctuations. Agric. Meteorol. 9, 163-181.

Kowalski, A.S., Sánchez-Cañete, E.P., 2010. A New Definition of the Virtual Temperature, Valid for the Atmosphere and the CO 2 -Rich Air of the Vadose Zone. J. Appl. Meteorol. Climatol. 49, 1692-1695. doi:10.1175/2010JAMC2534.1

Kuang, X., Jiao, J.J., Li, H., 2013. Review on airflow in unsaturated zones induced by natural forcings. Water Resour. Res. 49, 6137-6165. doi:10.1002/wrcr.20416

Laguerre, O., Ben Amara, S., Alvarez, G., Flick, D., 2008. Transient heat transfer by free convection in a packed bed of spheres: Comparison between two modelling approaches and experimental results. Appl. Therm. Eng. 28, 14-24. doi:10.1016/j.applthermaleng.2007.03.014

Lahmira, B., Barbour, L., Huang, M., 2014a. Numerical Modeling of Gas Flow in the Suncor Coke Stockpile Covers. Vadose Zo. J. 13, 1-12. doi:10.2136/vzj2013.07.0119

Lahmira, B., Lefebvre, R., Hockley, D., Phillip, M., 2014b. Atmospheric Controls on Gas Flow 
513 Lebeau, M., Konrad, J.-M., 2009. Natural convection of compressible and incompressible gases 514 in undeformable porous media under cold climate conditions. Comput. Geotech. 36, 435445. doi:10.1016/j.compgeo.2008.04.005

Maier, M., Schack-Kirchner, H., 2014. Using the gradient method to determine soil gas flux: A

Massman, W.J., Sommerfeld, R.A., Mosier, A.R., Zeller, K.F., Hehn, T.J., Rochelle, S.G., 1997. review. Agric. For. Meteorol. 192-193, 78-95. doi:10.1016/j.agrformet.2014.03.006

Moldrup, P., Olesen, T., Yoshikawa, S., Komatsu, T., Rolston, D.E., 2004. Three-Porosity Model for Predicting the Gas Diffusion Coefficient in Undisturbed Soil. Soil Sci. Soc. Am.

Nachshon, U., Dragila, M., Weisbrod, N., 2012. From atmospheric winds to fracture ventilation: J. 68, 750-759. doi:10.2136/sssaj2004.0750 Cause and effect. J. Geophys. Res. Biogeosciences 117, 1-11. doi:10.1029/2011JG001898

Nachshon, U., Weisbrod, N., Dragila, M.I., 2008. Quantifying Air Convection through SurfaceExposed Fractures: A Laboratory Study. Vadose Zo. J. 7, 948-956.

doi:10.2136/vzj2007.0165

Nachshon, U., Weisbrod, N., Dragila, M.I., Grader, A., 2011. Combined evaporation and salt precipitation in homogeneous and heterogeneous porous media. Water Resour. Res. 47, 1-

533 Neeper, D.A., 2002. Investigation of the vadose zone using barometric pressure cycles. J. 
Contam. Hydrol. 54, 59-80. doi:10.1016/S0169-7722(01)00146-2

535 Nield, D. a., Kuznetsov, a. V., 2013. An Historical and Topical Note on Convection in Porous Media. J. Heat Transfer 135, 06120-1-06120-10. doi:10.1115/1.4023567

Nield, D.A., 2004. Comments on "“The onset of transient convection in bot- tom heated porous media."” Int. J. Heat Mass Transf. 47, 641-643.

Nield, D.A., Bejan, A., 2006. Convection in porous media, Second. ed. Springer, NY.

Ninari, N., Berliner, P.R., 2002. The role of dew in the water and heat balance of bare loess soil in the Negev Desert: quantifying the actual dew deposition on the soil surface. Atmos. Res. 64, 323-334. doi:10.1016/S0169-8095(02)00102-3

Poulsen, T.G., Moldrup, P., 2006. Evaluating effects of wind-induced pressure fluctuations on soil-atmosphere gas exchange at a landfill using stochastic modelling. Waste Manag. Res. 24, 473-481. doi:10.1177/0734242X06066363

Poulsen, T.G., Sharma, P., 2011. Apparent Porous Media Gas Dispersion in Response to Rapid Pressure Fluctuations. Soil Sci. 176, 635-641. doi:10.1097/SS.0b013e3182372fae

Reicosky, D.C., Gesch, R.W., Wagner, S.W., Gilbert, R.A., Wente, C.D., Morris, D.R., 2008. Tillage and wind effects on soil CO2 concentrations in muck soils. Soil Tillage Res. 99, 221-231. doi:10.1016/j.still.2008.02.006

551 Rose, a. W., Guo, W., 1995. Thermal convection of soil air on hillsides. Environ. Geol. 25, 258262. doi:10.1007/BF00766755

553 Rossabi, J., Falta, R.W., 2002. Analytical Solution for Subsurface Gas Flow to a Well Induced by Surface Pressure Fluctuations. Ground Water 40, 67-75. doi:10.1111/j.17456584.2002.tb02492.x 
Smith, A.B., Walker, J.P., Western, A.W., Young, R.I., Ellett, K.M., Pipunic, R.C., Grayson, R.B., Siriwardena, L., Chiew, F.H.S., Richter, H., 2012. The Murrumbidgee soil moisture monitoring network data set. Water Resour. Res. 48, 1-6. doi:10.1029/2012WR011976

Sørensen, J.P., Stewart, W.E., 1974. Computation of forced convection in slow flow through ducts and packed beds-IV. Convective boundary layers in cubic arrays of spheres. Chem. Eng. Sci. 29, 819-825. doi:10.1016/0009-2509(74)80202-2

Takle, E.S., Massman, W.J., Brandle, J.R., Schmidt, R.A., Zhou, X., Litvina, I. V., Garcia, R., Doyle, G., Rice, C.W., 2004. Influence of high-frequency ambient pressure pumping on

Tan, K.K., Sam, T., 1999. Simulations of the onset of transient convection in porous media under

Tillman, F.D., Smith, J.A., 2005. Site Characteristics Controlling Airflow in the Shallow

Tan, K.-K., Sam, T., Jamaludin, H., 2003. The onset of transient convection in bottom heated fixed surface temperature boundary conditions, in: Second International Conference on

CFD in the Minerals and Process Industries. Melbourne, Australia, pp. 175-180. porous media. Int. J. Heat Mass Transf. 46, 2857-2873. doi:10.1016/S0017-9310(03)00045-

Turcu, V.E., Jones, S.B., Or, D., 2005. Continuous Soil Carbon Dioxide and Oxygen Unsaturated Zone in Response to Atmospheric Pressure Changes. Environ. Eng. Sci. 22, 25-37. doi:10.1089/ees.2005.22.25

577 Measurements and Estimation of Gradient-Based Gaseous Flux. Vadose Zo. J. 4, 11611169. doi:10.2136/vzj2004.0164 
578 Turner, J.S., Pinshow, B., 2015. Transient-state mechanisms of wind-induced burrow ventilation.

$579 \quad$ J. Exp. Biol. 218, 170-175. doi:10.1242/jeb.110858

580 Waddington, E.D., Cunningham, J., Harder, S.L., 1996. The Effects Of Snow Ventilation on

581 Chemical Concentrations, in: Wolff, E.W., Bales, R.C. (Eds.), Chemical Exchange Between

582 the Atmosphere and Polar Snow. Springer Berlin Heidelberg, Berlin, Heidelberg, pp. 403-

583 451. doi:10.1007/978-3-642-61171-1_18

584 Weisbrod, N., Dragila, M.I., 2006. Potential impact of convective fracture venting on salt-crust

585 buildup and ground-water salinization in arid environments. J. Arid Environ. 65, 386-399.

$586 \quad$ doi:10.1016/j.jaridenv.2005.07.011

587 Weisbrod, N., Dragila, M.I., Nachshon, U., Pillersdorf, M., 2009. Falling through the cracks: The

588 role of fractures in Earth-atmosphere gas exchange. Geophys. Res. Lett. 36, 1-5.

589 doi:10.1029/2008GL036096

590 You, K., Zhan, H., 2013. Comparisons of diffusive and advective fluxes of gas phase volatile 591 organic compounds (VOCs) in unsaturated zones under natural conditions. Adv. Water

592 Resour. 52, 221-231. doi:10.1016/j.advwatres.2012.11.021

593

594 


\section{Figure captions}

596 Fig. 1. Soil temperature difference between the soil surface and $1 \mathrm{~m}$ below the surface, and

597 surface wind measured $3.5 \mathrm{~m}$ above the land surface during a summer (a) and a winter (b) day.

598 Data taken from the Ben-Gurion University Meteorological Station located at Sede Boqer. Red

599 zones labeled TD represent time segments with unstable density gradients potentially leading to

$600 \mathrm{TCV}$, and blue zones represent wind conditions (SW) that could potentially lead to WIC

601 according to similar wind velocities that activated WIC in fractures (Nachshon et al., 2012). Note

602 that the maximum observed wind of $6 \mathrm{~m} \mathrm{~s}^{-1}$ at an elevation of $3.5 \mathrm{~m}$ corresponds to $1.5 \mathrm{~m} \mathrm{~s}^{-1}$ at

$603 \quad 0.1 \mathrm{~m}$ above the surface (Nachshon et al., 2012)

604 Fig. 2. Experimental setting. (a) Scheme of the column showing sensor locations (modified from

605 Ganot et al., 2014), (b) A photo of the overall system located within the climate-controlled

606 laboratory.

607 Fig. 3. Continuous temperature profiles obtained by fitting an exponential function (Eq. 5) to

608 each dataset, for different particle sizes (PSs) and temperature differences (TDs). (a) TD1 = $3.5 \pm$

$6090.5^{\circ} \mathrm{C}$, (b) $\mathrm{TD} 2=6.5 \pm 0.5^{\circ} \mathrm{C} . \mathrm{R}^{2}>0.96$ for the entire dataset.

610 Fig. 4. Calculated $R a$ profiles (Eqs. 3, 5, and 6) for different media particle sizes (PSs) under

611 different imposed temperature differences (TDs). (a) $\mathrm{TD} 1=3.5 \pm 0.5^{\circ} \mathrm{C}$, (b) $\mathrm{TD} 2=6.5 \pm 0.5^{\circ} \mathrm{C}$.

$612 R a_{\text {critical }}$ equals 27.1 (Tan and Sam, 1999; Tan et al., 2003). TCV stage represents conditions that

613 exceed the theoretical $R a_{\text {critical }}$ values for the onset of TCV. Reference depth represents the $\mathrm{CO}_{2}$

614 sensor location in the porous media $0.9 \mathrm{~m}$ below the surface and $0.15 \mathrm{~m}$ above the lower

615 boundary of the porous media with the gas chamber.

616 Fig. 5. Correlations between convection cell length and (a) relative concentration, (b) differences 
617 between the $\left[\mathrm{CO}_{2}\right]$ at $0.3-\mathrm{m}$ and $0.9-\mathrm{m}$ depths. Regression lines exclude data from experiments in

618 which no TCV transport was observed: PS = $1 \mathrm{~cm}$ for TD1 and TD2; and PS = $2 \mathrm{~cm}$ for TD1.

619 Convection cell lengths were based on $R a$ numbers presented in Fig. 4, and relative

620 concentrations were calculated using Eq. 4. Error bars represent a 5\% deviation from the

621 average.

622 Fig. 6. Vertical distribution of three parameters in a theoretical soil profile, at two different

623 times. (a) 04:00 AM, and (b) 08:00 AM. (a1, b1): Temperature profile calculated with Eqs. 7 and

624 8. For a1: $\mathrm{T}_{\mathrm{avg}}=20^{\circ} \mathrm{C}, \mathrm{A}_{0}=10^{\circ} \mathrm{C}, \mathrm{t}=72000 \mathrm{sec}, \alpha_{\mathrm{s}}=5 \times 10^{-7} \mathrm{~m}^{2} \mathrm{~s}^{-1}$ corresponding to dry sand

625 conditions (Al Nakshabandi and Kohnke, 1965). For b1: $\mathrm{t}=86400$. For a 2 and $\mathrm{b} 2: d T / d Z$ as a

626 function of depth using the first derivative of Eq. 7. For a3 and b3: Ra number as a function of

627 depth calculated by substituting $d T / d Z$ into Eq. 1, $\mathrm{k}=1.6 \times 10^{-7} \mathrm{~m}^{2}$ (same as the 1-cm PS

628 experiments), $\mathrm{H}=\mathrm{d}$. Constants used for air at $20^{\circ} \mathrm{C}: \beta=3.4 \times 10^{-3}{ }^{\circ} \mathrm{C}^{-1}$ and $v=1.5 \times 10^{-5} \mathrm{~m}^{2} \mathrm{~s}^{-1}$

629 (Incropera et al., 2007). TCV stage represents conditions of $R a>R a_{\text {critical, }}$ indicating onset of

$630 \mathrm{TCV}$. The $R a$ value for positive (stable) temperature gradients is set to $R a=0$. Note that the $R a$

631 axis is in $\log$ scale.

632 


\section{3 (Figure 1)}

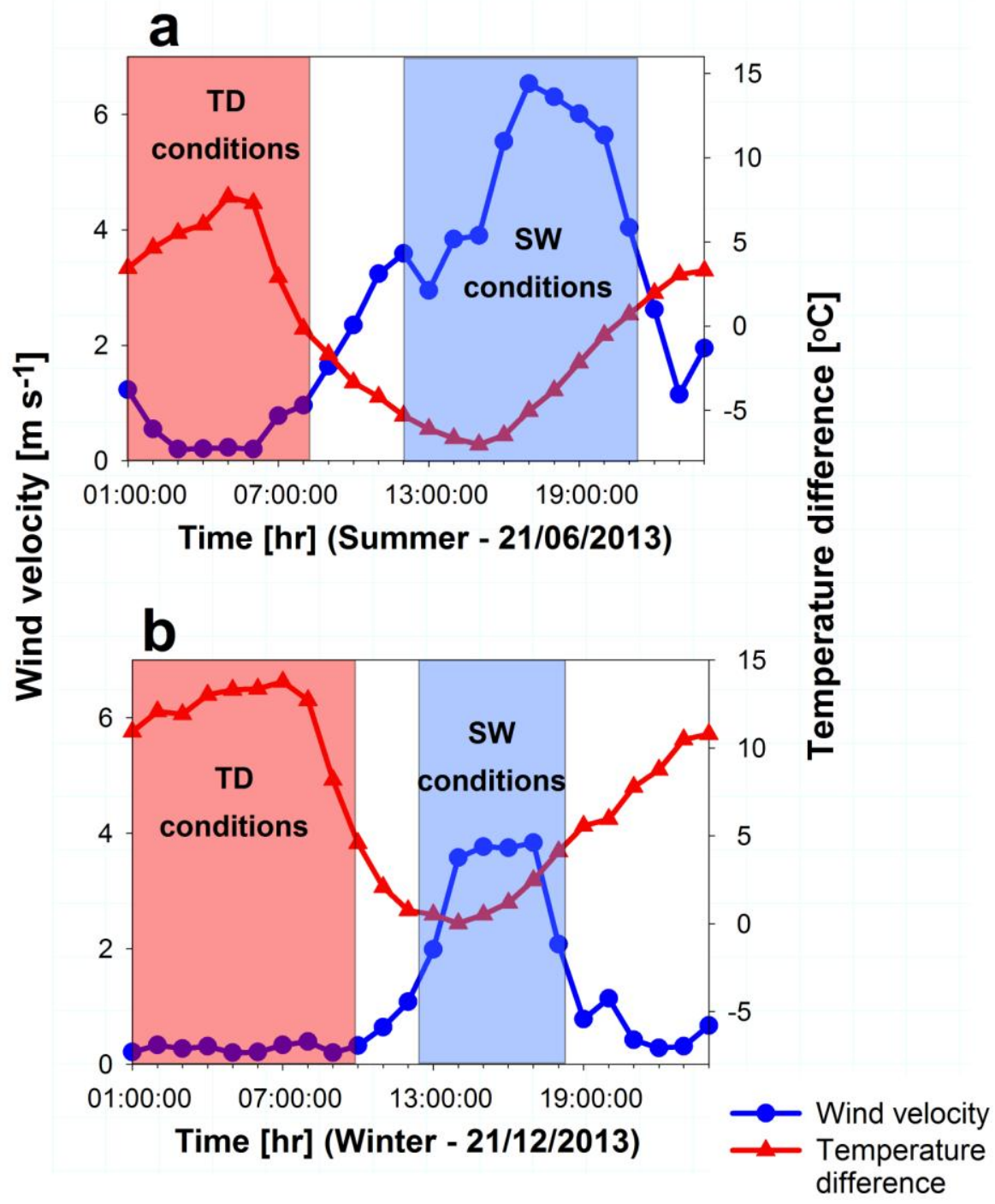


636 (Figure 2)

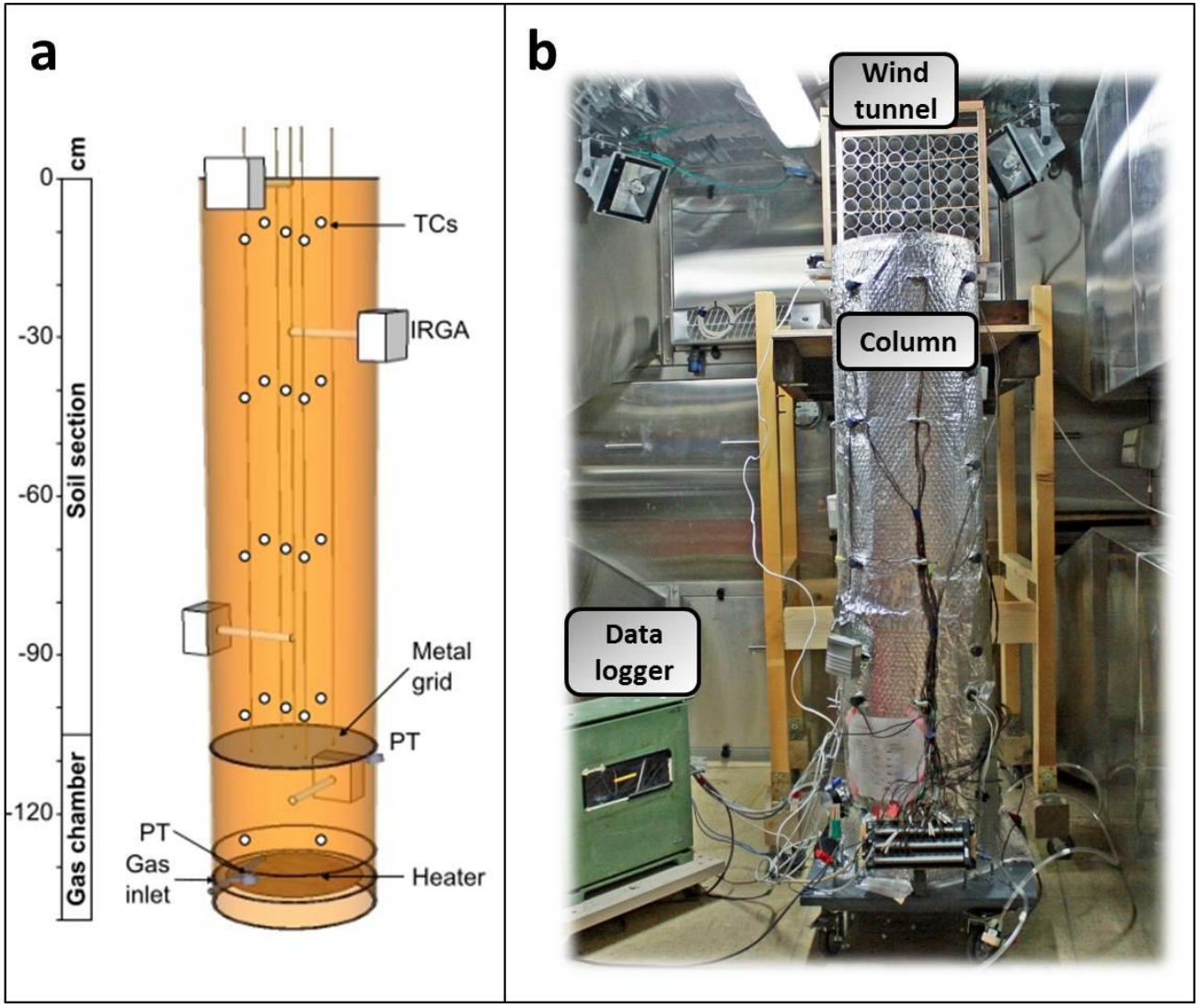


638 (Figure 3)

Temperature $\left[{ }^{\circ} \mathrm{C}\right]$
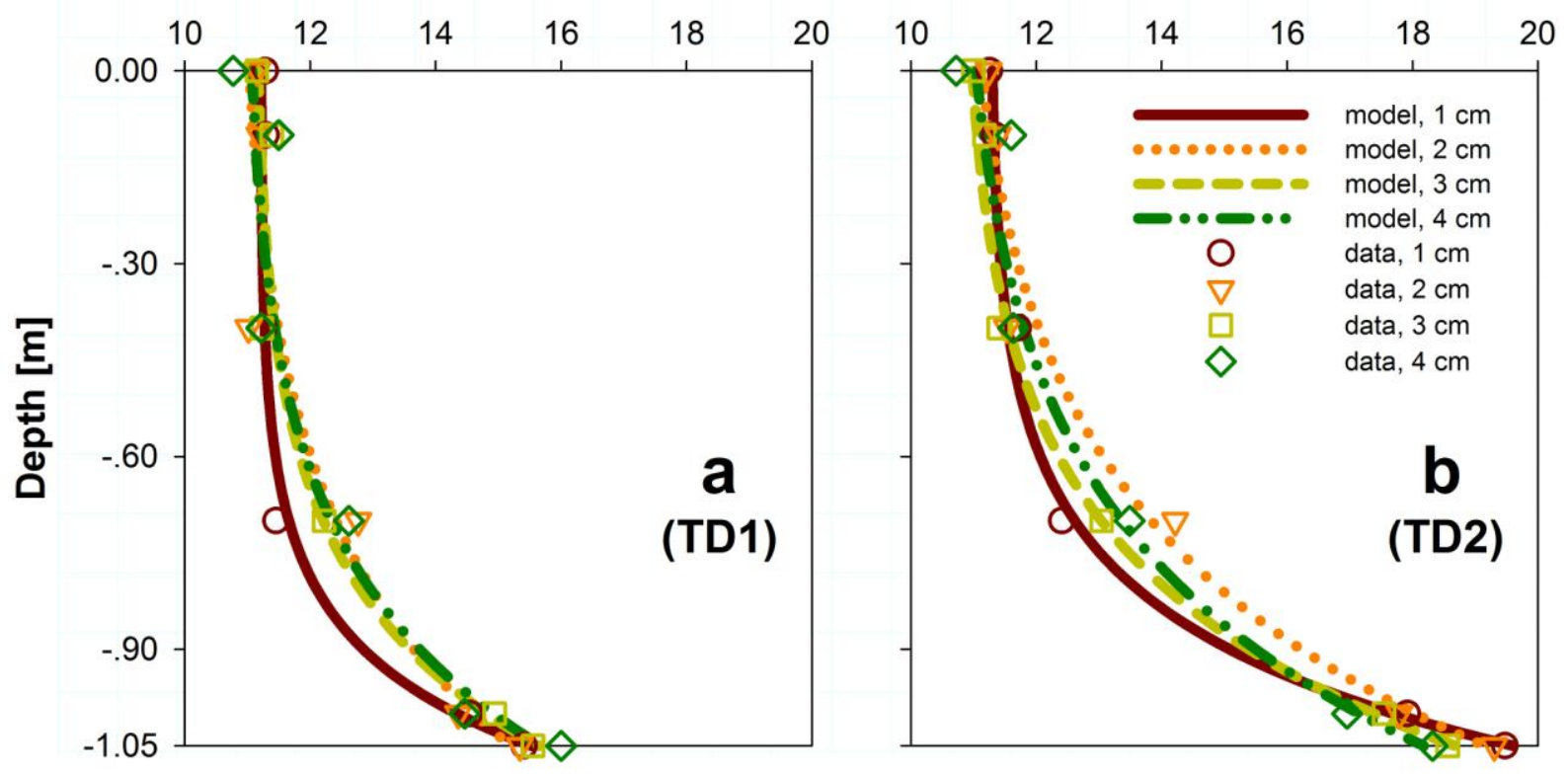

639 


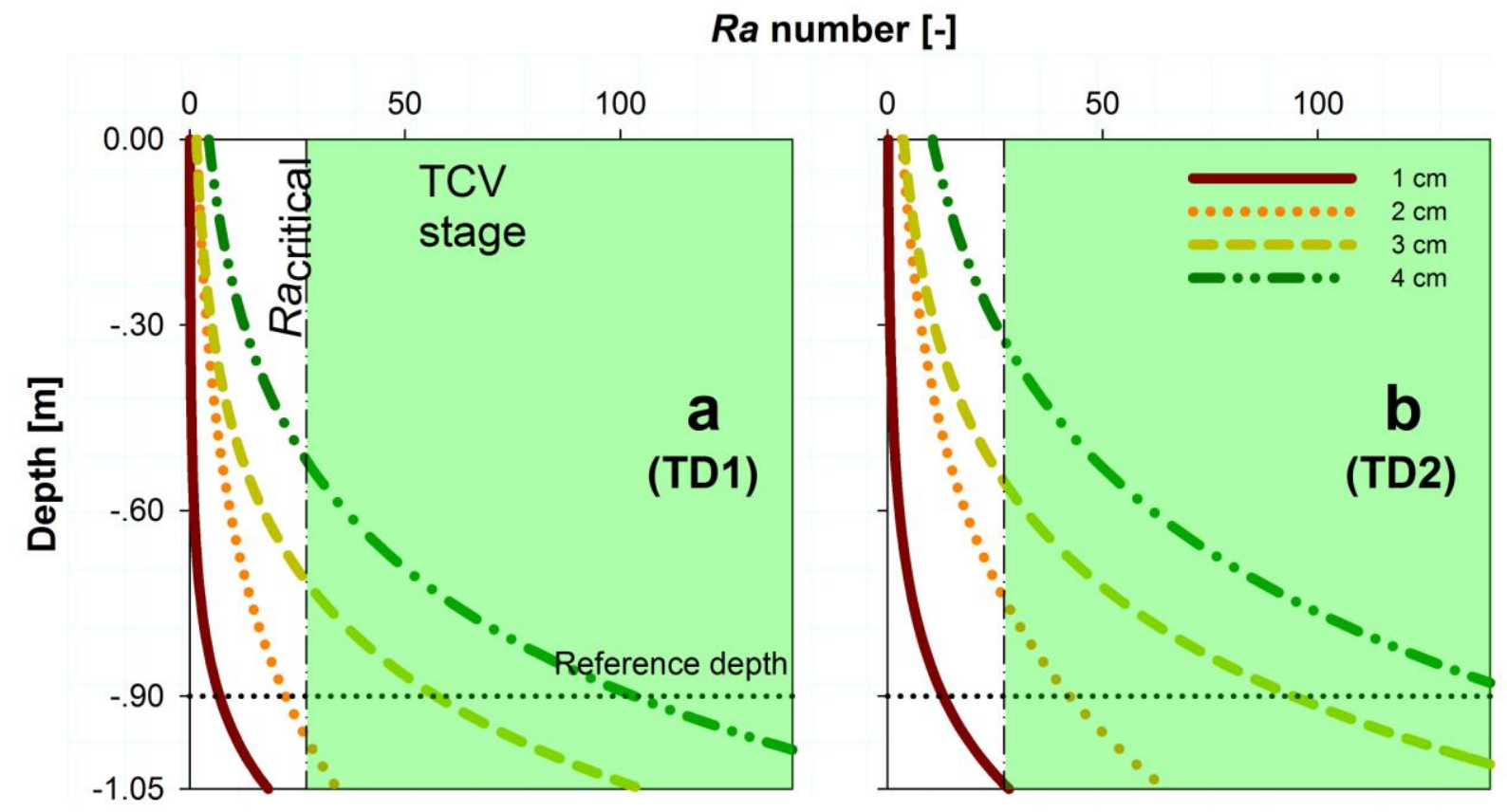


642 (Figure 5)
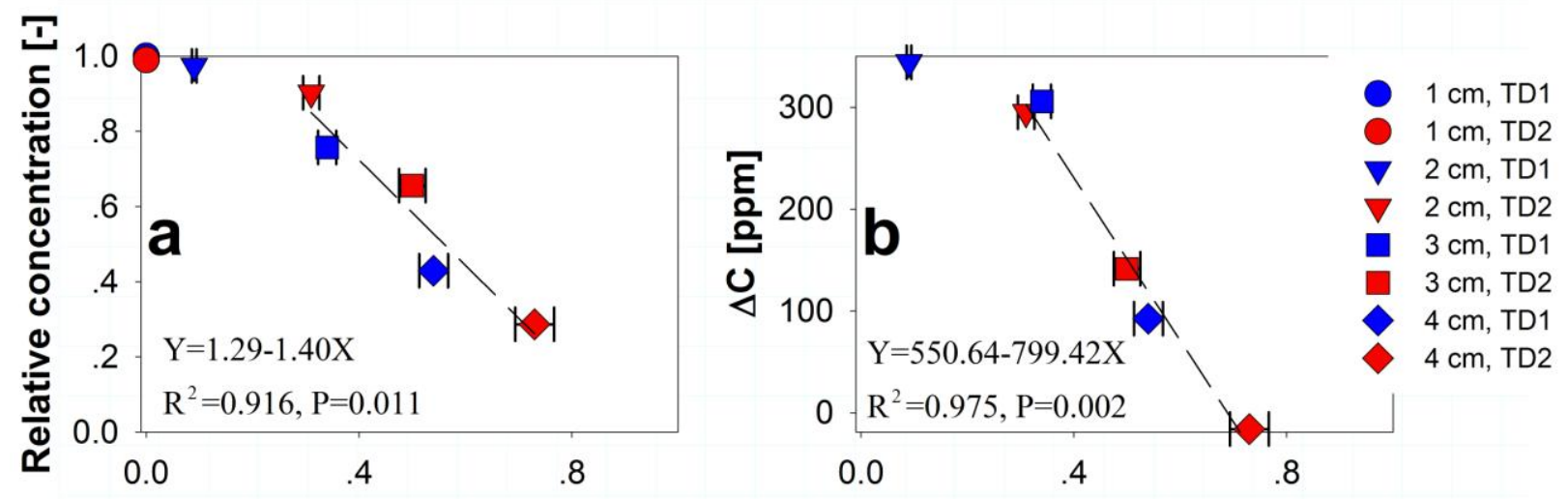

643

Convection cell length [m] 
644 (Figure 6)

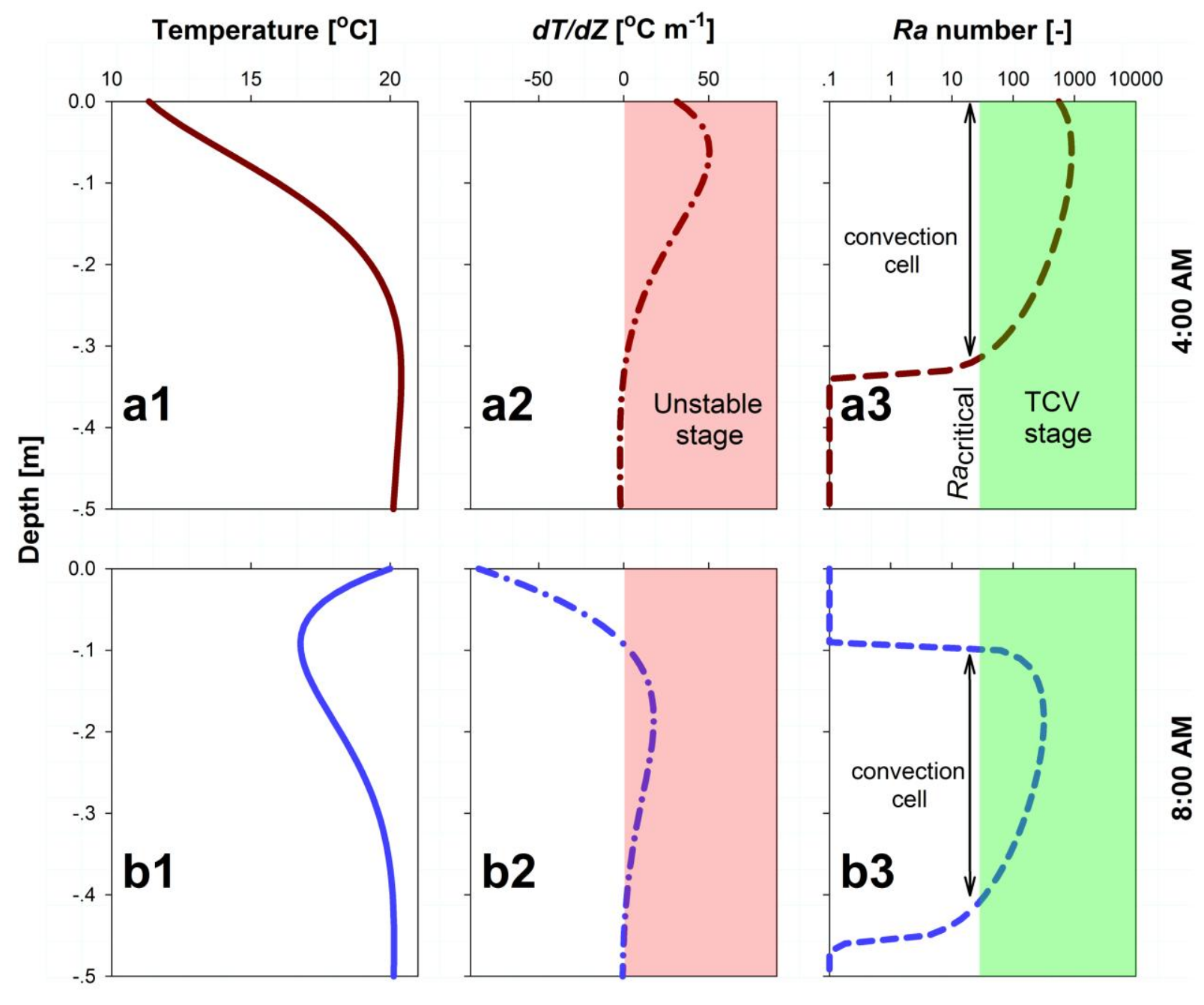


647 Table 1. Summarized results organized by particle size (PS)

\begin{tabular}{|c|c|c|c|c|c|c|c|}
\hline$A$ & B & C & D & $E$ & $\mathrm{~F}$ & G & $\mathrm{H}$ \\
\hline $\begin{array}{c}\text { Column } \\
\text { properties }^{a}\end{array}$ & Conditions & $\begin{array}{c}\text { Temperature } \\
\text { differences } \\
\text { (TD) }{ }^{\mathrm{b}} \\
{\left[{ }^{\circ} \mathrm{C}\right]}\end{array}$ & $\begin{array}{c}\mathrm{CO}_{2} \\
\text { reading } \\
\text { at }-0.9 \\
{[\mathrm{ppm}]}\end{array}$ & $\begin{array}{c}\text { Relative } \\
\text { concentration } \\
\text { at }-0.9[\mathrm{ppm}]\end{array}$ & $\begin{array}{c}\mathrm{CO}_{2} \\
\text { reading at } \\
-0.3[\mathrm{ppm}]\end{array}$ & $\begin{array}{c}\text { Convection } \\
\text { cell length } \\
{[\mathrm{m}] \mathrm{d}}\end{array}$ & $R a_{\text {avg }}$ \\
\hline \multirow[t]{2}{*}{$1 \mathrm{~cm} \mathrm{PS}$} & TD0 & $-0.35 \pm 0.06$ & $1909 \pm 4$ & $1 \pm 0$ & $1845 \pm 47$ & 0 & $\approx 0$ \\
\hline & TD1 & $3.26 \pm 0.15$ & $1915 \pm 10$ & $1 \pm 0$ & $1840 \pm 3$ & 0 & $\approx 0$ \\
\hline \multirow[t]{2}{*}{$\mathrm{k}=1.6 \times 10^{-7} \mathrm{~m}^{2}$} & TD2 & $3.53 \pm 0.03$ & $1919 \pm 5$ & $1.01 \pm 0$ & $1841 \pm 4$ & 0.01 & 28.7 \\
\hline & SW & $-0.12 \pm 0.07$ & $1899 \pm 10$ & $0.99 \pm 0$ & $1827 \pm 6$ & N/A & N/A \\
\hline \multirow[t]{2}{*}{$f=0.45$} & TD1 with SW & $6.66 \pm 0.08$ & $1906 \pm 2$ & $1 \pm 0$ & $1811 \pm 22$ & N/A & N/A \\
\hline & TD2 with SW & $6.63 \pm 0.16$ & $1909 \pm 7$ & $1 \pm 0$ & $1804 \pm 33$ & N/A & N/A \\
\hline \multirow[t]{2}{*}{$2 \mathrm{~cm}$ PS } & TDO & $-0.4 \pm 0.04$ & $1955 \pm 2$ & $1 \pm 0$ & $1576 \pm 47$ & 0 & $\approx 0$ \\
\hline & TD1 & $3.2 \pm 0.10$ & $1914 \pm 10$ & $0.97 \pm 0.01$ & $1570 \pm 51$ & 0.09 & 32.3 \\
\hline \multirow[t]{2}{*}{$\mathrm{k}=6.5 \times 10^{-7} \mathrm{~m}^{2}$} & TD2 & $6.5 \pm 0.02$ & $1800 \pm 32$ & $0.90 \pm 0.02$ & $1505 \pm 47$ & 0.31 & 45.1 \\
\hline & SW & $-0.4 \pm 0.04$ & $1942 \pm 3$ & $0.99 \pm 0$ & $1284 \pm 45$ & N/A & $\mathrm{N} / \mathrm{A}$ \\
\hline \multirow[t]{2}{*}{$f=0.45$} & TD1 with SW & $3.6 \pm 0.04$ & $1920 \pm 6$ & $0.98 \pm 0.01$ & $1352 \pm 17$ & N/A & N/A \\
\hline & TD2 with SW & $6.4 \pm 0.06$ & $1759 \pm 37$ & $0.88 \pm 0.02$ & $1268 \pm 70$ & N/A & $\mathrm{N} / \mathrm{A}$ \\
\hline \multirow[t]{2}{*}{$3 \mathrm{~cm}$ PS } & TD0 & $-0.5 \pm 0.12$ & $1872 \pm 20$ & $1 \pm 0$ & $1225 \pm 174$ & 0 & $\approx 0$ \\
\hline & TD1 & $3.8 \pm 0.03$ & $1506 \pm 43$ & $0.76 \pm 0.03$ & $1201 \pm 39$ & 0.34 & 60 \\
\hline \multirow[t]{2}{*}{$\mathrm{k}=1.3 \times 10^{-6} \mathrm{~m}^{2}$} & TD2 & $6.5 \pm 0.07$ & $1353 \pm 21$ & $0.66 \pm 0.01$ & $1212 \pm 19$ & 0.5 & 78.1 \\
\hline & SW & $-0.2 \pm 0.02$ & $1873 \pm 21$ & $1 \pm 0.02$ & $1006 \pm 49$ & N/A & N/A \\
\hline \multirow[t]{2}{*}{$f=0.44$} & TD1 with SW & $3.9 \pm 0.05$ & $1643 \pm 7$ & $0.85 \pm 0.01$ & $1101 \pm 15$ & N/A & N/A \\
\hline & TD2 with SW & $6.7 \pm 0.03$ & $1141 \pm 45$ & $0.52 \pm 0.03$ & $1011 \pm 47$ & N/A & N/A \\
\hline \multirow[t]{2}{*}{$4 \mathrm{~cm}$ PS } & TD0 & $-0.5 \pm 0.08$ & $1655 \pm 13$ & $1 \pm 0$ & $978 \pm 57$ & 0 & $\approx 0$ \\
\hline & TD1 & $3.7 \pm 0.0 .13$ & $919 \pm 29$ & $0.43 \pm 0.02$ & $827 \pm 30$ & 0.54 & 79.3 \\
\hline \multirow[t]{2}{*}{$\mathrm{k}=2.4 \times 10^{-6} \mathrm{~m}^{2}$} & TD2 & $6.2 \pm 0.12$ & $735 \pm 24$ & $0.29 \pm 0.02$ & $751 \pm 22$ & 0.73 & 96.2 \\
\hline & SW & $-0.2 \pm 0.01$ & $1766 \pm 26$ & $1.09 \pm 0.03$ & $887 \pm 49$ & N/A & $\mathrm{N} / \mathrm{A}$ \\
\hline \multirow[t]{2}{*}{$f=0.45$} & TD1 with SW & $3.4 \pm 0.14$ & $868 \pm 37$ & $0.39 \pm 0.03$ & $751 \pm 26$ & N/A & N/A \\
\hline & TD2 with SW & $6.3 \pm 0.71$ & $484 \pm 35$ & $0.09 \pm 0.03$ & $594 \pm 38$ & N/A & $\mathrm{N} / \mathrm{A}$ \\
\hline
\end{tabular}

648 Average and standard deviation values calculated from three experiment repetitions. ${ }^{\text {a }}$

649 Permeability was calculated using Eq. 2. ${ }^{\mathrm{b}}$ TDs between the bottom of the porous media in the

650 column and the air inside the laboratory. ${ }^{\mathrm{c}}$ Relative concentration was calculated using Eq. $4 .{ }^{\mathrm{d}}$

651 Calculations in columns $\mathrm{G}$ and $\mathrm{H}$ are explained in section 3.2. N/A represents the conditions in

652 which $R a$ number calculations are not applicable due to an additional wind mechanism. 